\title{
Development of a New Semiselective Medium for Isolating Xanthomonas campestris pv. manihotis from Plant Material and Soil
}

\author{
Anania Fessehaie, Kerstin Wydra, and Klaus Rudolph
}

First and third authors: Institut für Pflanzenpathologie und Pflanzenschutz der Universität, Grisebachstr. 6, 37077 Göttingen, Germany; and second author: International Institute of Tropical Agriculture, Cotonou, Benin, West Africa.

Accepted for publication 4 February 1999.

\begin{abstract}
Fessehaie, A., Wydra, K., and Rudolph, K. 1999. Development of a new semiselective medium for isolating Xanthomonas campestris pv. manihotis from plant material and soil. Phytopathology 89:591-597.

An effective control for bacterial blight of cassava (Manihot esculenta), caused by Xanthomonas campestris pv. manihotis, requires the use of noncontaminated cuttings and seeds. Using classical agar plating techniques for screening planting material for contamination has not been very successful because of the lack of a reliable semiselective agar medium. The pathogen grows slowly on general plating media and is easily overgrown by saprophytic bacteria during isolation from diseased plants. In an effort to develop a semiselective medium, the utilization of several carbon and nitrogen sources was studied. Results of these tests provided information used to design a basal medium allowing good growth of the target organism while suppressing growth of several common saprophytes. Additional selectivity was achieved by incorporating three antibiotics into the basal
\end{abstract}

ABSTRACT medium. The new semiselective agar medium, designated cefazolin trehalose agar (CTA) medium, contained (per liter) $3.0 \mathrm{~g}$ of $\mathrm{K}_{2} \mathrm{HPO}_{4}, 1.0 \mathrm{~g}$ of $\mathrm{NaH}_{2} \mathrm{PO}_{4}, 0.3 \mathrm{~g}$ of $\mathrm{MgSO}_{4} \cdot 7 \mathrm{H}_{2} \mathrm{O}, 1.0 \mathrm{~g}$ of $\mathrm{NH}_{4} \mathrm{Cl}, 9.0 \mathrm{~g}$ of $\mathrm{D}(+)$-trehalose, $1.0 \mathrm{D}(+)$-glucose, $1.0 \mathrm{~g}$ of yeast extract, $0.025 \mathrm{~g}$ of cefazolin, $0.0012 \mathrm{~g}$ of lincomycin, $0.0025 \mathrm{~g}$ of phosphomycin, $0.25 \mathrm{~g}$ of cycloheximide, and $14.0 \mathrm{~g}$ of agar. In comparison to a starch-based semiselective medium (SXM), plating efficiencies using pure cultures of 10 strains of $X$. campestris pv. manihotis were significantly higher on CTA, with an average of 85 and $50 \%$, respectively. Likewise, isolation and recovery of X. campestris pv. manihotis from infected cassava leaves and contaminated soil were much higher on CTA than on SXM agar. When X. campestris pv. manihotis occurs in high concentrations in diseased tissue, the standard yeast trehalose glucose agar medium supplemented with $250 \mu \mathrm{g}$ of cycloheximide per ml appears to be satisfactory. The newly developed CTA medium should prove useful for control strategies to identify and remove infected planting material of cassava, as well as for basic ecological studies of the pathogen.
Cassava bacterial blight (CBB), caused by Xanthomonas campestris pv. manihotis, is a major constraint to cassava (Manihot esculenta Crantz) cultivation, and losses can be extremely severe in regions where highly susceptible cultivars are grown (22). On the basis of genotypic studies, Vauterin et al. (34) recently proposed a reclassification of Xanthomonas, renaming the CBB organism $X$. axonopodis pv. manihotis. However, since this change is not widely known and not yet accepted by the scientific community, we will use $X$. campestris pv. manihotis to avoid confusion. The pathogen was first reported in Brazil (4) and later observed in several additional countries of South America (20), Africa (14,33,35,38), and Asia (5). In Africa, losses have exceeded 50\% (22).

$X$. campestris pv. manihotis is a Gram-negative, nonpigmented slender rod with a single polar flagellum (6). The pathogen penetrates via stomata or through wounds in epidermal tissues of leaves and young shoots, invades the vascular tissue, causes extensive breakdown of parenchymatous tissue (32), and results in watersoaking to brown-blighting symptoms (22). Since the pathogen invades its host systemically, transmission by vegetative propagation of cassava is often overlooked.

Sustainable control of the bacterial pathogen can be obtained by the use of integrated control measures (agronomic, biological, and chemical) in addition to varietal resistance (21). Breeding for resistance is a time-consuming process, and until cassava cultivars with durable resistance against $\mathrm{CBB}$ are available, the disease will need

Corresponding author: K. Rudolph; E-mail address: krudolp@gwdg.de

Publication no. P-1999-0518-01R

(c) 1999 The American Phytopathological Society to be controlled by hygienic measures. Since the pathogen is seedborne $(10,12,24)$ and survives as an epiphyte $(9,12,24)$, sensitive detection methods are needed to screen seed lots and cuttings used for propagation.

In contrast to most other xanthomonads, colonies of $X$. campestris pv. manihotis are white on agar media and are, therefore, somewhat more difficult to distinguish from many naturally occurring saprophytes. In addition, the pathogen is often overgrown by saprophytic bacteria during isolation from infected plants; so a semiselective medium is needed. A starch-based medium (SXM) designed by Leksomboon et al. (19) for isolating X. campestris pv. manihotis proved not to be useful because most African strains failed to grow on SXM. Therefore, to facilitate control of the disease by eradicating infected cuttings and to carry out epidemiological studies, we designed a new semiselective agar medium.

\section{MATERIALS AND METHODS}

Bacterial strains. Twenty-nine original strains of $X$. campestris pv. manihotis were isolated in Africa, and eleven were received from collections (Table 1). The pathotype strain (GSPB no. 2337) was obtained from the International Collection of Microorganisms from Plants (ICMP no. 5741), New Zealand. New strains were isolated from leaves and stems of cassava plants from Benin, Nigeria, and Uganda and were maintained on yeast glucose chalk agar at $14^{\circ} \mathrm{C}(31)$. The freshly isolated strains were tested for pathogenicity on 6-week-old, susceptible plants of the local cultivar Agric from Benin as previously described (11).

One strain of $X$. campestris pv. cassavae and several epiphytic strains were included (Table 1). The bacteria were maintained on slants of yeast glucose chalk medium (31) by transferring every 6 months. 
For long-term preservation, strains were lyophilized in evaporated skim milk as a cryopreservative.

Carbon and nitrogen utilization. The capability to utilize different carbon compounds was determined by supplementing a defined agar medium (per liter: $3.0 \mathrm{~g}$ of $\mathrm{K}_{2} \mathrm{HPO}_{4}, 1.0 \mathrm{~g}$ of $\mathrm{NaH}_{2} \mathrm{PO}_{4}$, $0.3 \mathrm{~g}$ of $\mathrm{MgSO}_{4} \cdot 7 \mathrm{H}_{2} \mathrm{O}, 1.0 \mathrm{~g}$ of $\mathrm{NH}_{4} \mathrm{Cl}$, and $14.0 \mathrm{~g}$ of agar-agar no. 1 from Nordwald Co., Hamburg, Germany) with $1.0 \%$ of the following carbon sources: soluble potato starch (no. 101252; E. Merck AG, Darmstadt, Germany), $\alpha$-D-lactose, D(+)-galactose, D(+)-cellobiose, $\mathrm{D}(+)$-trehalose, melibiose, methylsuccinic acid, 2-oxoglutaric acid, bromosuccinic acid, citrate, L-proline, and glycerol (Sigma Chemical Co., St. Louis). Inorganic nitrogen sources were tested in the defined agar medium containing $1 \%$ glucose and no $\mathrm{NH}_{4} \mathrm{Cl}$. Peptone was tested as an organic nitrogen source and $\left(\mathrm{NH}_{4}\right)_{2} \mathrm{SO}_{4}, \mathrm{NH}_{4} \mathrm{Cl}$, and $\mathrm{NH}_{4} \mathrm{H}_{2} \mathrm{PO}_{4}$ as inorganic nitrogen sources.

L-Glutamic acid and L-methionine were tested for their growthpromoting effects as proposed by Starr (30). In these experiments, $0.1 \%$ L-glutamic acid or $0.02 \% \mathrm{~L}$-methionine was added to the defined agar medium containing $1 \% \mathrm{D}(+)$-trehalose. The $\mathrm{pH}$ of the basal medium was 7.1 prior to autoclaving and was not adjusted.

After determining the nutritional requirements of $X$. campestris pv. manihotis, growth of strains on the newly developed agar media was compared with growth on the SXM medium of Leksomboon et al. (19) (per liter: $0.8 \mathrm{~g}$ of $\mathrm{K}_{2} \mathrm{HPO}_{4}, 0.6 \mathrm{~g}$ of $\mathrm{KH}_{2} \mathrm{PO}_{4}, 0.7 \mathrm{~g}$ of yeast extract, $8.0 \mathrm{~g}$ of soluble starch, $1.0 \mathrm{~g}$ of glucose, and $14.0 \mathrm{~g}$ of agar) without addition of the antibiotics and biological stains. The number of colony forming units (CFU) was determined by dilution-plating methods, and plating efficiencies were expressed as the percentage of colonies grown on test media compared with the standard medium, which was nutrient glucose agar (NGA) (per liter: $8.0 \mathrm{~g}$ of nutrient broth, $10.0 \mathrm{~g}$ of glucose, $3.0 \mathrm{~g}$ of yeast extract, and $14.0 \mathrm{~g}$ of agar). Several semiselective media proposed for other xanthomonads were tested for the growth of $X$. campestris pv. manihotis including XCS (28) and modified D-5 media (18), Tween medium (23), and Tween-cellobiose medium $(1,2)$ designed for $X$. campestris pv. carotae, $X$. campestris pv. vesicatoria, and $X$. campestris pv. pelargonii, respectively.
Resistance to antibiotics. The resistance of $X$. campestris pv. manihotis to antibiotics was determined by the technique of Bauer et al. (3). Commercially available discs containing different concentrations of antibiotics were used. Bacterial suspensions in $0.01 \mathrm{M}$ $\mathrm{MgSO}_{4}$ were prepared from 1- to 2-day-old NGA cultures, and the concentration was adjusted to approximately $1 \times 10^{8} \mathrm{CFU}$ per $\mathrm{ml}$. The bacterial suspension was streaked evenly onto the surface of the NGA medium with a cotton swab dipped into the inoculum. After 10 to $20 \mathrm{~min}$, discs were placed on the agar with sterile forceps and gently pressed down to ensure contact. The plates were incubated at $28^{\circ} \mathrm{C}$ overnight, and the diameter of the inhibition zones were measured (including the 6-mm discs). A reading of $6 \mathrm{~mm}$ indicated no inhibition. The discs producing no inhibition zone did not necessarily indicate a suitable antibiotic for a X. campestris pv. manihotis medium, because the diffusion and solubility properties of the drugs might be limiting factors. For this reason, those antibiotics that showed no inhibition of $X$. campestris pv. manihotis by the disc technique of Bauer et al. (3), but that inhibited epiphytic bacteria (Erwinia herbicola, Pseudomonas fluorescens, and others) (discussed below), were further evaluated by incorporation of the antibiotics into basal yeast trehalose glucose agar (YTGA), as described below. Aliquots of $0.1 \mathrm{ml}$ of each of three strains $(2363,2369$, and 2592) were plated at concentrations of $10^{3}$ and $10^{2} \mathrm{CFU} / \mathrm{ml}$ onto each of three plates. Cefazolin (C5020; Sigma Chemical Co., St. Louis), lincomycin (L6004; Sigma), phosphomycin (P5396; Sigma), and thiamphenicol (T0261; Sigma) were included in these studies, because $X$. campestris pv. manihotis was reported to be resistant to the latter two antibiotics (13).

Combinations of several antibiotics were also tested in YTGA. In these experiments, cycloheximide was added at $250 \mu \mathrm{g} / \mathrm{ml}$ to inhibit fungal growth. Stock solutions of the antibiotics $(100 \mathrm{mg}$ of cefazolin in $10 \mathrm{ml}$ of deionized water; $120 \mathrm{mg}$ of lincomycin in $10 \mathrm{ml}$ of $75 \%$ methanol; $25 \mathrm{mg}$ of phosphomycin in $10 \mathrm{ml}$ of deionized water, and $2,100 \mathrm{mg}$ of cycloheximide in $8.4 \mathrm{ml}$ of $75 \%$ ethanol) were filter-sterilized and stored in sterile screw-cap flasks at $5^{\circ} \mathrm{C}$. All antibiotics were added aseptically to the basal medium at a temperature of $45^{\circ} \mathrm{C}$ after autoclaving.

TABLE 1. Origin of strains of Xanthomonas campestris pv. manihotis and other species used to evaluate semiselective media

\begin{tabular}{|c|c|c|c|c|}
\hline GSPB $^{\mathrm{x}}$ no. & Strain designation & Origin & Isolated & Isolated by \\
\hline \multirow[t]{2}{*}{$2363 ; 2373$} & J $12 ; \mathrm{J} 17$ & Nigeria & 1993 & K. Wydra \\
\hline & J $1-$ J $11 ;$ J $13-$ J 16, J 19 & Nigeria & 1993 & K. Wydra \\
\hline $2364 ; 2593$ & I 1, I 2 & Nigeria & 1993 & Wydra \& Verdier \\
\hline 2285 & ORST 42 & Nigeria & 1978 & J. F. Daniel \\
\hline 2360 & O 4 & Nigeria & 1993 & K. Wydra \\
\hline \multirow[t]{2}{*}{2359} & IITA $3 c$ & Benin & 1994 & K. Wydra \\
\hline & IITA 1, IITA 7, IITA 7a, IITA 7b, IITA 7c, Zoundja & Benin & 1994 & K. Wydra \\
\hline 2369 & $\mathrm{Ug} 21$ & Uganda & 1994 & B. Boher \\
\hline 2286 & ORST 41 & Republic of Central Africa & 1977 & J. F. Daniel \\
\hline 2391 & PC 3 & Cameroon & 1994 & K. Wydra \\
\hline 2282 & ORST 212 & Cameroon & 1992 & V. Verdier \\
\hline 2272 & ORST 187 & Zaire & 1987 & B. Boher \\
\hline 2287 & UPB 031 (Xanthomonas campestris pv. cassavae) & Rwanda & 1977 & H. Maraite \\
\hline 3001 & CIAT 1203 & Dominican Republic & 1981 & J. Lozano \\
\hline 2348 & CIAT 1222 & Brazil & 1984 & J. Lozano \\
\hline 2350 & NCPPB 2444 & Colombia & 1970 & J. Lozano \\
\hline 2355 & CIAT 1180 & Venezuela & 1977 & J. Lozano \\
\hline 1713 & Pseudomonas fluorescens & Hungary & 1988 & Z. Klement \\
\hline \multirow[t]{2}{*}{450} & Erwinia herbicola, NCPPB 601 & United Kingdom & 1958 & R. A. Lelliott \\
\hline & PB E1, PB E2, PB E2b, PB E4, PB E5a, PB E5b z & Benin & 1993 & K. Wydra \\
\hline
\end{tabular}

${ }^{\mathrm{x}} \mathrm{GSPB}=$ Göttingen Collection (Sammlung) of Phytopathogenic Bacteria.

y $2337=$ Pathotype strain.

${ }^{\mathrm{z}}$ Typical epiphytic bacteria from cassava. 
Efficiency and selectivity of the newly developed semiselective medium compared with SXM medium. Ten strains of $X$. campestris pv. manihotis $(2337,2348,2350,2355,2356,2359$, $2360,2364,2369$, and 2391) were used to evaluate growth on the newly designed, semiselective cefazolin trehalose agar (CTA) medium, in comparison with SXM and NGA. Bacterial cultures grown for $48 \mathrm{~h}$ at $30^{\circ} \mathrm{C}$ on NGA were suspended in sterile $0.85 \% \mathrm{NaCl}$ (saline) and adjusted to a turbidity of $\mathrm{OD}_{590}=0.3$ (corresponding to a viable cell count of approximately $1 \times 10^{8} \mathrm{CFU} / \mathrm{ml}$ ). Five serial 10 -fold dilutions were made in sterile saline, and $0.1 \mathrm{ml}$ from the $10^{-4}$ and $10^{-5}$ dilutions was plated onto each of three plates of the different media. Colony counts ranging from 10 to 1,000 were made after incubation for $48 \mathrm{~h}$ at $30^{\circ} \mathrm{C}$ and averaged.

Isolation of $X$. campestris pv. manihotis from naturally infected cassava leaves and recovery from inoculated leaf homogenates. Leaf samples from five cassava cultivars were collected during the dry season in February 1997 from Ina, North Benin. Samples were placed in paper bags and sent via courier mail to Göttingen and analyzed within a week. Small tissue pieces of cassava were homogenized with a sterile mortar and pestle in $10 \mathrm{ml}$ of sterile saline. The homogenate was vortexed for approximately $30 \mathrm{~s}$ and aliquoted into 5 and $4.5 \mathrm{ml}$. The 5 - $\mathrm{ml}$ homogenate was used for isolation and the latter for the recovery assay. After thoroughly mixing, the 5-ml homogenate was diluted serially to $10^{-3}$, and $0.1-\mathrm{ml}$ aliquots of each 10 -fold dilution were plated onto the media. Plates were incubated for $48 \mathrm{~h}$ at $30^{\circ} \mathrm{C}$.

To determine recovery rates, the $4.5-\mathrm{ml}$ homogenate prepared above was vortexed with $0.5 \mathrm{ml}$ of a suspension of $X$. campestris pv. manihotis, strain 2359 (approximately $10^{6} \mathrm{CFU} / \mathrm{ml}$ ), serially diluted, and plated onto the media (NGA, CTA, and SXM) as described above.

Isolation and recovery of $X$. campestris pv. manihotis from soil. Soil samples (dry, sandy clay) were collected from cassava fields in February 1997 from different localities in Cotonou, South Benin; Ina, North Benin; and Ibadan, West Nigeria. Soil samples were mailed to Göttingen the same way as cassava leaf samples.

One gram of field-collected soil was suspended in $5 \mathrm{ml}$ of sterile saline, vortexed, diluted serially to $10^{-3}$, and $0.1-\mathrm{ml}$ aliquots of each 10-fold dilution were plated onto the media in three repetitions and incubated as described above. To test recovery, $0.5 \mathrm{ml}$ of a bacterial suspension (approximately $10^{6} \mathrm{CFU} / \mathrm{ml}$ ) was added to $1 \mathrm{~g}$ of soil suspended in $4.5 \mathrm{ml}$ and processed as described above.

\section{RESULTS}

Carbon and nitrogen utilization. Growth of $X$. campestris pv. manihotis on semiselective media proposed for other pathovars of $X$. campestris was unsatisfactory and, thus, none of these media were suitable for $X$. campestris pv. manihotis. All the carbon sources tested, except soluble starch, bromosuccinic acid, and citrate, supported good growth of the two strains tested (2275 and 2296). Because the growth of $X$. campestris pv. manihotis strains on starch medium was poor, an additional 225 strains of $X$. campestris pv. manihotis were tested for starch hydrolysis as previously described

TABLE 2. Plating efficiency (\%) of three Xanthomonas campestris pv. manihotis strains on different nutrient media compared with the standard medium $(\mathrm{NGA})^{\mathrm{z}}$

\begin{tabular}{lccccc}
\hline Strains & NGA & SXM & YTGA & GTGA & GTA \\
\hline 2373 & 100 & 107 & 140 & 151 & 129 \\
2592 & 100 & 77 & 147 & 160 & 145 \\
2369 & 100 & 94 & 127 & 167 & 137 \\
Colony diameter (mm) & $2-3$ & $2-3$ & $2-3$ & $1.5-3$ & $1.5-2$ \\
$\quad$ After (h) & $48 \mathrm{~h}$ & $48 \mathrm{~h}$ & $48 \mathrm{~h}$ & $72 \mathrm{~h}$ & $96 \mathrm{~h}$ \\
\hline
\end{tabular}

${ }^{\mathrm{z}} \mathrm{NGA}=$ Nutrient broth glucose agar; SXM = medium of Leksomboon et al. (19), tested without antibiotics and biological stains; YTGA = yeast trehalose glucose agar; GTGA = glutamate trehalose glucose agar; and GTA = glutamate trehalose agar.
$(26,36)$. The results showed distinct differences in the ability of these strains to degrade starch $(11,38)$. Therefore, starch was not chosen as a carbon source for $X$. campestris pv. manihotis. $\mathrm{D}(+)-$ Trehalose was found to be the best carbon source, because all strains of $X$. campestris pv. manihotis grew on it equally well. $\mathrm{D}(+)-\mathrm{Cel}-$ lobiose was equivalent to $\mathrm{D}(+)$-trehalose, but it had to be added aseptically after autoclaving. Both of the tested saprophytes, $P$. fluorescens (GSPB no. 1713) and E. herbicola (GSPB no. 450) grew on all carbon sources except bromosuccinic acid. Few differences were observed in growth of $X$. campestris pv. manihotis on the three inorganic nitrogen sources tested. Ammonium chloride $(0.1 \%)$ appeared to be the best inorganic nitrogen source and was chosen.

The basal medium, designated glutamate trehalose agar (GTA) medium, contained the following ingredients per liter: $3.0 \mathrm{~g}$ of $\mathrm{K}_{2} \mathrm{HPO}_{4}$, $1.0 \mathrm{~g}$ of $\mathrm{NaH}_{2} \mathrm{PO}_{4}, 0.3 \mathrm{~g}$ of $\mathrm{MgSO}_{4} \cdot 7 \mathrm{H}_{2} \mathrm{O}, 1.0 \mathrm{~g}$ of $\mathrm{NH}_{4} \mathrm{Cl}, 10.0 \mathrm{~g}$ of $\mathrm{D}(+)$-trehalose, $1.0 \mathrm{~g}$ of L-glutamic acid, and $14.0 \mathrm{~g}$ of agar.

Evaluation and modification of basal GTA medium. Because $X$. campestris pv. manihotis colonies failed to grow on GTA beyond a 2-mm diameter after $96 \mathrm{~h}$ of incubation at $30^{\circ} \mathrm{C}$, the initially formulated GTA medium was modified by (i) reducing trehalose to $0.9 \%$ and adding $0.1 \%$ glucose (glutamate trehalose glucose agar [GTGA] medium) and (ii) substituting $0.1 \%$ L-glutamic acid with $0.1 \%$ yeast extract (yeast trehalose glucose agar; YTGA). The $\mathrm{pH}$ was not adjusted and cycloheximide was added as above. The plate counts of three strains of $X$. campestris pv. manihotis on GTA, GTGA, YTGA, and SXM media were compared with NGA (Table 2). Plating efficiency on YTGA was higher than on SXM and NGA media (135 to $191 \%$ and 127 to $147 \%$, respectively) and was equal to SXM and NGA in terms of colony diameter and growth rate. Plating efficiency was highest on GTGA, but bacterial growth was slower than on YTGA, which was, therefore, chosen for further studies.

Resistance to antibiotics. The two strains of $X$. campestris pv. manihotis and one strain of $X$. campestris pv. cassavae tested were resistant to cefazolin, lincomycin, and mupirocin and weakly resistant to Targocid (teicoplanin; Hoechst Marion Roussel, Frankfurt, Germany) (Table 3). The inhibition zones of $X$. campestris pv. cassavae were equal to or larger than those of $X$. campestris pv. manihotis strains. These four antibiotics were further tested with a larger group of $X$. campestris pv. manihotis strains using the single-disc method of Bauer et al. (3). These studies revealed that all the antibiotics tested, except cefazolin and lincomycin, inhibited some strains of $X$. campestris pv. manihotis (Table 3). Therefore, cefazolin and lincomycin were used in further studies as well as phosphomycin, which was reported not to affect $X$. campestris pv. manihotis (13). The maximum tolerable concentrations of cefazolin,

TABLE 3. The reaction of bacterial strains toward four selected antibiotics

\begin{tabular}{lcccc}
\hline \multirow{2}{*}{$\begin{array}{l}\text { Bacterial strains } \\
\text { as received }\end{array}$} & \multicolumn{4}{c}{ Effect on Xanthomonas campestris pv. manihotis growth } \\
\cline { 2 - 5 } & Cefazolin & Lincomycin & Targocid & Mupirocin \\
\hline J 1- J 15; J 17; J 19 & $0^{\mathrm{y}}$ & 0 & 0 & 0 \\
Xm 5, Ug 21 & 0 & 0 & 0 & 0 \\
IITA 1, 3c, 7, 7a, 7b, 7c & 0 & 0 & 0 & 0 \\
Zoundja $^{\mathrm{x}}$ & 0 & 0 & 0 & 0 \\
ORST 1 & 0 & 0 & 4 & 14 \\
ORST 36 & 0 & 0 & 4 & 4 \\
ORST 41, ORST 212 & 0 & 0 & 0 & 0 \\
ORST 42 & 0 & 0 & 6 & 0 \\
ORST 187x & 0 & 0 & 0 & 14 \\
CFBP 1860 & 0 & 0 & 14 & 19 \\
CIAT 1203 & 0 & 0 & 4 & 0 \\
PB E1 & 0 & 0 & 0 & 0 \\
PB E2 & 26 & 0 & 0 & 0 \\
PB E2b & 0 & 0 & 15 & 17 \\
PB E4 & 26 & 0 & 0 & 0 \\
PB E5a & 14 & 0 & 0 & 0 \\
PB E5b & 24 & 0 & 16 & 18 \\
\hline
\end{tabular}

${ }^{\mathrm{x}} X$. campestris pv. manihotis.

y Diameter of the inhibition zone in millimeters.

z Typical accompanying bacteria. 
lincomycin, and phosphomycin were $100,1.2$, and $2.5 \mu \mathrm{g} / \mathrm{ml}$, respectively (Table 4).

Growth of $X$. campestris pv. manihotis on YTGA media supplemented with mixed antibiotics. After determining the optimal concentration for cefazolin, lincomycin, and phosphomycin, growth of $X$. campestris pv. manihotis was determined on three combinations of YTGA containing antibiotics and unmodified YTGA. Plating efficiencies ([average number of CFU per plate $\div$ average number of CFU per plate on YTGA] $\times 100$ ) were $80 \%$ with $25 \mu \mathrm{g}$ of cefazolin per $\mathrm{ml}$ and $1.2 \mu \mathrm{g}$ of lincomycin per $\mathrm{ml} ; 70 \%$ with $50 \mu \mathrm{g}$ of cefazolin per $\mathrm{ml}$ and $1.2 \mu \mathrm{g}$ of lincomycin per $\mathrm{ml}$; and $86 \%$ with $25 \mu \mathrm{g}$ of cefazolin per $\mathrm{ml}, 1.2 \mu \mathrm{g}$ of lincomycin per $\mathrm{ml}$, and $2.5 \mu \mathrm{g}$ of phosphomycin per ml. All the media contained $250 \mu \mathrm{g}$ of cycloheximide per $\mathrm{ml}$ to inhibit fungal growth. These experiments resulted in the following composition of the final semiselective medium, designated CTA medium, per liter: $3.0 \mathrm{~g}$ of $\mathrm{K}_{2} \mathrm{HPO}_{4}, 1.0 \mathrm{~g}$ of $\mathrm{NaH}_{2} \mathrm{PO}_{4}, 0.3 \mathrm{~g}$ of $\mathrm{MgSO}_{4} \cdot 7 \mathrm{H}_{2} \mathrm{O}, 1.0 \mathrm{~g}$ of $\mathrm{NH}_{4} \mathrm{Cl}, 9.0 \mathrm{~g}$ of $\mathrm{D}(+)-$ trehalose, $1.0 \mathrm{~g}$ of $\mathrm{D}(+)$-glucose, $1.0 \mathrm{~g}$ of yeast extract, $0.025 \mathrm{~g}$ of cefazolin, $0.0012 \mathrm{~g}$ of lincomycin, $0.0025 \mathrm{~g}$ of phosphomycin, $0.25 \mathrm{~g}$ of cycloheximide, and $14.0 \mathrm{~g}$ of agar.

Efficiency and selectivity of the newly developed semiselective medium compared with SXM medium. The media were compared for recovery of 10 strains of $X$. campestris pv. manihotis (Table 5). The CTA medium supported good growth of all 10 strains tested. Plating efficiencies for the 10 strains of $X$. campestris pv.

TABLE 4. Growth of Xanthomonas campestris pv. manihotis strains on yeast trehalose glucose agar medium supplemented with different concentrations of cefazolin, lincomycin, phosphomycin, or thiamphenicol

\begin{tabular}{lcc}
\hline Antibiotic & $\mu \mathrm{g} / \mathrm{ml}$ & Strains $^{\mathrm{y}}$ \\
\hline Cefazolin & 25 & + \\
& 50 & + \\
Lincomycin & 100 & + \\
& $1^{\mathrm{z}}$ & + \\
& $10^{\mathrm{z}}$ & $(+)$ \\
Phosphomycin & $100^{\mathrm{z}}$ & - \\
& 2.5 & + \\
& 5.0 & - \\
Thiamphenicol & 10.0 & - \\
& 2.5 & - \\
& 5.0 & - \\
\hline
\end{tabular}

${ }^{\mathrm{y}}$ X. campestris pv. manihotis strains 2363,2592 , and 2369. $+=$ Growth; $(+)=$ slightly suppressed; and $-=$ no growth.

${ }^{\mathrm{z}}$ Concentration of lincomycin is given in International Units (IU) and $1 \mathrm{IU} \cong$ $1.2 \mu \mathrm{g}$. manihotis ranged from 69 to $102 \%$, with an average of $85 \%$. Colonies of $X$. campestris pv. manihotis were white to creamy white, convex, 1.5 to $4.0 \mathrm{~mm}$ in diameter after 2 days, visible after $48 \mathrm{~h}$ at $30^{\circ} \mathrm{C}$, and had smooth margins. No morphological differences were observed between strains from different geographic origins. All strains of $X$. campestris pv. manihotis grew on SXM medium, and colonies appeared after 3 days of incubation at $30^{\circ} \mathrm{C}$, measuring $\leq 1.5 \mathrm{~mm}$ in diameter. Colonies were round, convex, and because of color interference in the medium, bluish white. Plating efficiencies ranged from 5 to $80 \%$, with an average of $50 \%$. SXM medium allowed only slow growth of some of the strains tested (Fig. 1).

Isolation of $X$. campestris pv. manihotis from naturally infected cassava leaves and recovery of $X$. campestris pv. manihotis 2359 from leaf tissue homogenate on NGA, CTA, and SXM. Isolation of $X$. campestris pv. manihotis was positive on all three media for four of five samples (Table 6). Colonies of $X$. campestris pv. manihotis were countable after $48 \mathrm{~h}$ on CTA and NGA and after $72 \mathrm{~h}$ on SXM. Saprophytic bacteria associated with cassava leaves failed to grow on CTA, and X. campestris pv. mani-

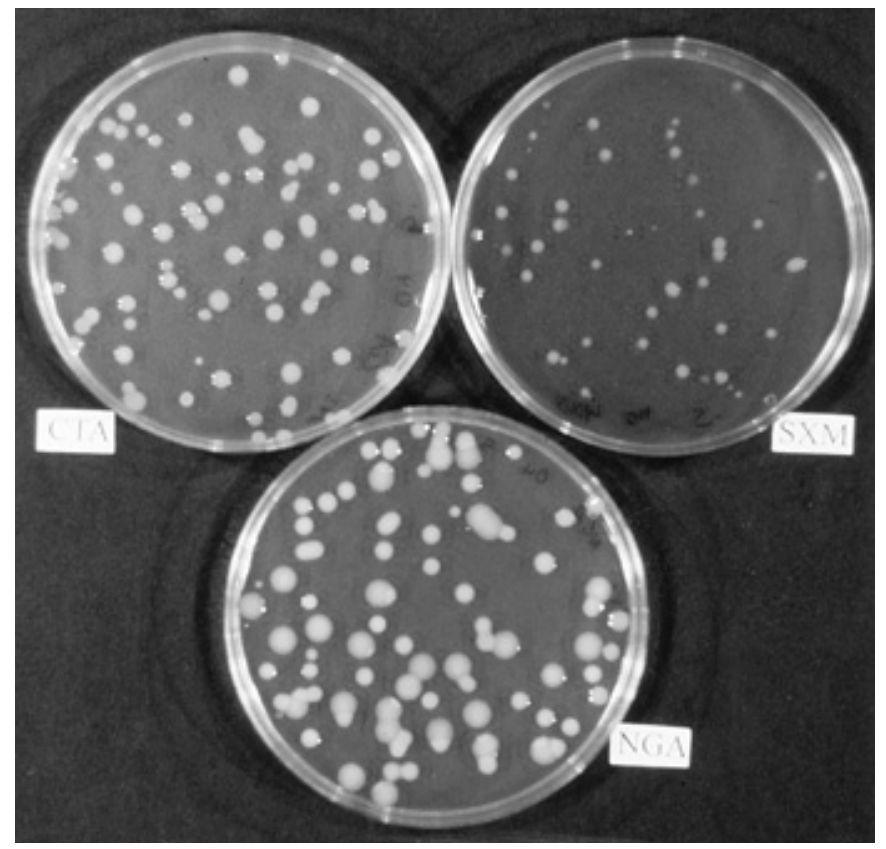

Fig. 1. Growth of Xanthomonas campestris pv. manihotis strain 2364 on cefazolin trehalose agar (CTA), medium of Leksomboon et al. (19) tested without antibiotics and biological stains (SXM), and nutrient broth glucose agar (NGA).

TABLE 5. Colony counts and plating efficiencies of 10 strains of Xanthomonas campestris pv. manihotis from different geographic origins on nutrient broth glucose agar (NGA), cefazolin trehalose agar (CTA), and medium of Leksomboon et al. (19) tested without antibiotics and biological stains (SXM) media

\begin{tabular}{|c|c|c|c|c|c|c|}
\hline \multirow[b]{2}{*}{$\mathrm{GSPB}^{\mathrm{x}}$ no. } & \multirow[b]{2}{*}{ Source } & \multicolumn{3}{|c|}{ No. of colonies per plate } & \multicolumn{2}{|c|}{ Plating efficiency ${ }^{\mathrm{y}}(\%)$} \\
\hline & & NGA & CTA & SXM & CTA & SXM \\
\hline 2359 & Benin & $580 \pm 95^{z}$ & $400 \pm 36$ & $27 \pm 29$ & 69 & 5 \\
\hline 2364 & Nigeria & $1,017 \pm 120$ & $737 \pm 95$ & $423 \pm 116$ & 73 & 42 \\
\hline 2391 & Cameroon & $290 \pm 30$ & $267 \pm 61$ & $40 \pm 10$ & 92 & 14 \\
\hline 2369 & Uganda & $797 \pm 119$ & $617 \pm 40$ & $150 \pm 27$ & 77 & 19 \\
\hline 2360 & Nigeria & $930 \pm 70$ & $750 \pm 87$ & $380 \pm 66$ & 81 & 41 \\
\hline 2355 & Venezuela & $674 \pm 24$ & $600 \pm 17$ & $516 \pm 7$ & 89 & 77 \\
\hline 2350 & Colombia & $632 \pm 18$ & $601 \pm 15$ & $488 \pm 8$ & 95 & 77 \\
\hline 2348 & Colombia & $550 \pm 10$ & $540 \pm 13$ & $429 \pm 57$ & 98 & 78 \\
\hline 2356 & Colombia & $269 \pm 5$ & $245 \pm 7$ & $212 \pm 10$ & 91 & 79 \\
\hline 2337 & Brazil & $601 \pm 19$ & $611 \pm 2$ & $478 \pm 50$ & 102 & 80 \\
\hline
\end{tabular}

${ }^{x}$ GSPB $=$ Göttingen Collection (Sammlung) of Phytopathogenic Bacteria.

${ }^{\mathrm{y}}$ Plating efficiency $=\frac{\text { average no. of CFU on CTA or SXM plate }}{\text { average no. of CFU on NGA plate }} \times 100$.

${ }^{\mathrm{z}}$ Average number of colonies per plate \pm standard error of the mean of three replications. Means of the total colony count for $X$. campestris pv. manihotis on NGA, CTA, and SXM media were 634, 537, and 314, respectively. Plating efficiencies for $X$. campestris pv. manihotis on CTA were significantly higher $(P=$ 0.05 ) than that on SXM medium (19), when Tuckey's new multiple range test was applied. 
hotis grew normally. In contrast, on NGA, either heavy growth of saprophytic bacteria overgrew colonies of $X$. campestris pv. manihotis or a few antagonistic bacteria suppressed its growth at dilutions of $10^{0}$ and $10^{-2}$ (Fig. 2). A similar effect on nonselective media was also described for $X$. campestris pv. campestris (8). On SXM, saprophytes were inhibited and growth of $X$. campestris pv. manihotis cells was observed at dilution $10^{\circ}$, but no $X$. campestris pv. manihotis colonies were recovered at dilution $10^{-2}$ (Fig. 2). The total number of colonies of $X$. campestris pv. manihotis recovered from naturally infected leaf samples on CTA was much higher than that on SXM medium; colonies per plate averaged 436 and 250 , respectively (Table 6). The recovery of $X$. campestris pv. manihotis on SXM medium required a higher concentration of the pathogen to be present in plant tissues as shown in Table 6 .

Recovery of $X$. campestris pv. manihotis from infested soils on CTA, SXM, and NGA. Isolation of $X$. campestris pv. manihotis from three native soils collected from cassava-growing fields was unsuccessful. After adding bacterial suspensions to the soils,

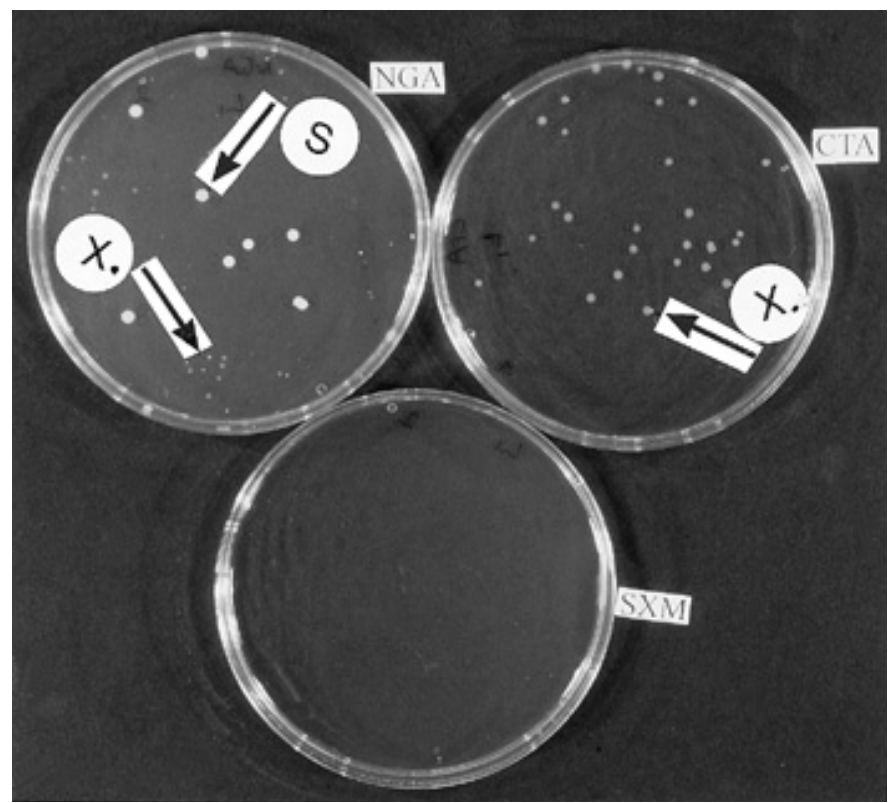

Fig. 2. Isolation of Xanthomonas campestris pv. manihotis from naturally infected, dry season-collected cassava leaf samples on cefazolin trehalose agar (CTA), medium of Leksomboon et al. (19) tested without antibiotics and biological stains (SXM), and nutrient broth glucose agar (NGA). Eight saprophytic bacterial colonies (arrow $\mathrm{S}$ ) inhibited the growth of $X$. campestris pv. manihotis colonies (arrow X) on NGA. Colonies of $X$. campestris pv. manihotis developed normally after $48 \mathrm{~h}$ at dilution $10^{-2}$ on CTA, but no colonies were visible on SXM. recovery of $X$. campestris pv. manihotis on NGA was impeded at all dilutions $\left(10^{-1}\right.$ to $\left.10^{-3}\right)$ by saprophytic soil bacteria. On CTA medium, colonies of $X$. campestris pv. manihotis were overgrown by saprophytes only at dilution $10^{-1}$. The recovery of $X$. campestris pv. manihotis at dilution $10^{-3}$ was $100 \%$ and higher than at dilution $10^{-2}$ (Fig. 3), with 3 and 15 colonies of saprophytic soil bacteria, respectively. On SXM medium, many saprophytes grew at dilution $10^{-1}$, but only a few grew at dilutions $10^{-2}$ and $10^{-3}$. X. campestris pv. manihotis colonies were never detected on SXM within $48 \mathrm{~h}$ after plating.

\section{DISCUSSION}

Currently, CBB can most effectively be controlled by hygienic measures, since cassava cultivars with good resistance to $\mathrm{CBB}$ are not always available. Since the pathogen is seedborne $(12,24)$ and survives as an epiphyte (12), sensitive detection methods are needed to screen seed lots and cuttings used for propagation. The most reliable method to detect bacteria in infected or infested seed and planting material is the use of semiselective agar media that suppress most of the accompanying epiphytic microflora and allow a

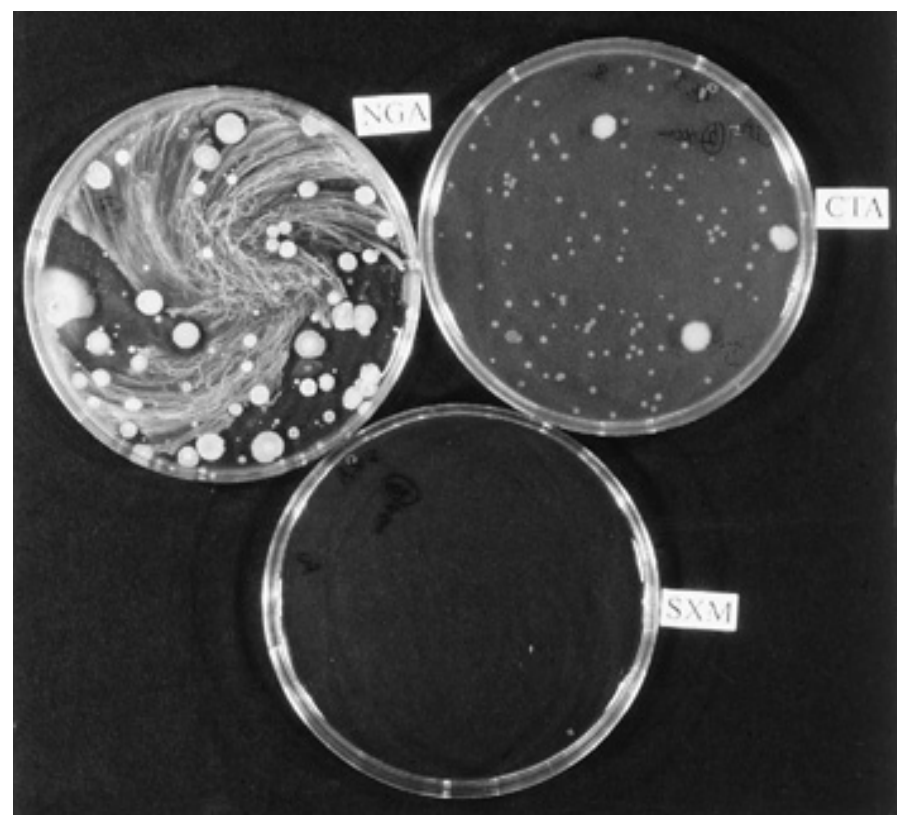

Fig. 3. Recovery of Xanthomonas campestris pv. manihotis strain 2359 from artificially infested soil on cefazolin trehalose agar (CTA), medium of Leksomboon et al. (19) tested without antibiotics and biological stains (SXM), and nutrient broth glucose agar (NGA) at dilution $10^{-3}$.

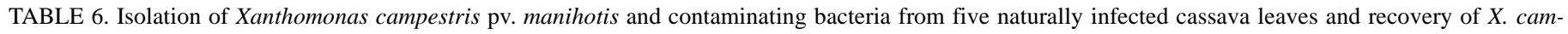

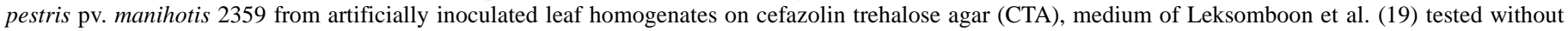
antibiotics and biological stains (SXM), and nutrient broth glucose agar (NGA)

\begin{tabular}{|c|c|c|c|c|c|c|c|c|c|}
\hline \multirow[b]{3}{*}{$\begin{array}{l}\text { Cassava } \\
\text { cultivar }\end{array}$} & \multicolumn{6}{|c|}{ Naturally infected tissue ${ }^{\mathrm{w}}$} & \multicolumn{3}{|c|}{ Artificially inoculated homogenate ${ }^{\mathrm{x}}$} \\
\hline & \multicolumn{2}{|c|}{ NGA } & \multicolumn{2}{|c|}{ CTA } & \multicolumn{2}{|c|}{ SXM } & \multirow{2}{*}{$\begin{array}{c}\text { NGA } \\
\text { X. campestris } \\
\text { pv. manihotis }\end{array}$} & \multirow{2}{*}{$\begin{array}{l}\text { CTA } \\
\text { X. campestris } \\
\text { pv. manihotis }\end{array}$} & \multirow{2}{*}{$\begin{array}{l}\text { SXM } \\
\text { X. campestris } \\
\text { pv. manihotis }\end{array}$} \\
\hline & $\begin{array}{l}\text { X. campestris } \\
\text { pv. manihotis }\end{array}$ & Contaminating & $\begin{array}{l}X . \text { campestris } \\
\text { pv. manihotis }\end{array}$ & Contaminating & $\begin{array}{l}\text { X. campestris } \\
\text { pv. manihotis }\end{array}$ & Contaminating & & & \\
\hline TMS 30572 & $38^{z}$ & 11 & 27 & 0 & 0 & 0 & 1,284 & 1,230 & 556 \\
\hline $084 / 00275$ & 0 & 0 & 0 & 0 & 0 & 0 & 880 & 772 & 445 \\
\hline 63397 & 158 & 2 & 102 & 0 & 72 & 0 & 1,295 & 1,150 & 508 \\
\hline $087 / 00611$ & 84 & 20 & 72 & 0 & 38 & 0 & 1,060 & 770 & 418 \\
\hline I82/00661 & 151 & 1 & 235 & 0 & 140 & 0 & 1,025 & 928 & 314 \\
\hline Total counts & 431 & 34 & 436 & 0 & 250 & 0 & 5,544 & 4,850 & 2,241 \\
\hline
\end{tabular}

${ }^{\mathrm{w}} \mathrm{CFU}$ mean of two plates in dilution $10^{-2}$.

${ }^{x}$ Recovery of a strain of $X$. campestris pv. manihotis (2359) added to leaf homogenates.

y Suspected colonies of $X$. campestris pv. manihotis.

${ }^{\mathrm{z}}$ Number of bacterial colonies per plate. 
direct identification and recovery of the pathogen (27). Ideally, a selective medium should encourage growth of all viable cells of the target bacteria and concomitantly exclude or suppress growth of all other groups of bacteria (25). However, selective media are almost never entirely selective so that the term "semiselective" is probably more appropriate in most cases.

From the 12 carbon and 3 nitrogen compounds tested, D(+)-trehalose and ammonium chloride were selected as primary carbon and nitrogen sources, respectively, for the new semiselective medium. All 18 strains of $X$. campestris pv. manihotis tested readily utilized both substrates. To enhance the growth rate of $X$. campestris pv. manihotis and allow evaluation of plates after $48 \mathrm{~h}$, glucose and yeast extract were added, both at $1.0 \mathrm{~g} / \mathrm{liter}$, to the final basal GTA medium. Of 20 antibiotics tested, 3 were included at optimal concentration. Cefazolin (16) inhibits Gram-negative bacteria, lincomycin (7) is active against Gram-positive bacteria, and phosphomycin $(15,37)$ has broad antibacterial action. This combination of antibiotics inhibited most bacterial contaminants commonly found on cassava plants. However, it should be noted that the diameters of the zones of inhibition are different for each chemical, not only because the disc potencies vary, but because the diffusion and solubility properties of the antibiotics in NGA medium also vary (3). This may be the main reason for the discrepancy in the previously reported resistance of $X$. campestris pv. manihotis strains to $25 \mu \mathrm{g}$ of thiamphenicol per ml (13), which was not confirmed in these studies when the antibiotics were added to the media in solution. The proposed semiselective CTA medium not only permits growth of $X$. campestris pv. manihotis, but also allows a good distinction of $X$. campestris pv. manihotis from saprophytes (Fig. 1) by colony characteristics.

The semiselective SXM medium designed by Leksomboon et al. (19) to isolate $X$. campestris pv. manihotis contains $0.8 \%$ soluble starch as a carbon source. However, analysis of $225 X$. campestris pv. manihotis strains from the Göttingen collection revealed considerable variation in ability of this pathovar to grow on starch (11). Plating efficiencies of all 40 strains of $X$. campestris pv. manihotis tested in this study were significantly higher (Tuckey's new multiple range test) on CTA than on SXM agar, and colonies were countable after $48 \mathrm{~h}$, in contrast to $72 \mathrm{~h}$ on SXM. Colony size was slightly reduced on SXM (Fig. 1). Other authors testing the growth of $X$. campestris pv. manihotis on the starch-containing media SM (8) and SX (29) also reported that plating efficiencies of $X$. campestris pv. manihotis strains were low ( 2 and $0 \%$, respectively) compared with the TZC medium of Kelman (17). These findings were in line with our work testing 225 strains of $X$. campestris pv. manihotis $(11,38)$. It can be assumed that the $X$. campestris pv. manihotis strains used by Leksomboon et al. (19) to evaluate SXM medium belonged to a group of strains that can degrade and metabolize starch as a primary energy source (Table 2). Our data show that starch is not a reliable carbon source for all strains of $X$. campestris pv. manihotis. We confirmed that two biological dyes, methyl violet 2B and methyl green, used in SXM medium (19) at 0.001 and $0.01 \mu \mathrm{g} / \mathrm{ml}$, respectively, suppressed growth of most soil bacteria, but unexpectedly also growth of most $X$. campestris $\mathrm{pv}$. manihotis colonies. Moreover, SXM agar was less transparent, and colonies of $X$. campestris pv. manihotis appeared bluish and were poorly differentiated morphologically from other starch-hydrolyzing bacteria.

Our isolation experiments from cassava leaves collected in the dry season showed that $X$. campestris pv. manihotis could be detected in low numbers on the new CTA medium; whereas on the standard NGA medium, no colonies of $X$. campestris pv. manihotis developed from undiluted samples. During the rainy growing season, when the CBB pathogen occurs in higher numbers, the use of the rather expensive semiselective CTA medium may not be necessary for routine testing. Instead, the pathogen should be easily isolated from diseased plants on yeast glucose agar medium (11), when supplemented with $200 \mathrm{ppm}$ of cycloheximide. CTA medium also proved to be very effective for isolating the pathogen from cassava field soils to which it had been added in low concentrations, whereas only $10 \%$ of the bacterial cells were reisolated on SXM medium (Fig. 3).

The newly developed semiselective CTA medium for $X$. campestris pv. manihotis should prove to be well suited for use in detecting infected plant material during vegetative propagation. Also, epidemiological studies will be considerably facilitated by the use of the semiselective medium.

\section{ACKNOWLEDGMENTS}

These studies were funded by the Federal Ministry for Economic Cooperation and Development, Bonn, Germany. We thank R. Rüchel, Hygiene-Institut der Universität Göttingen, for providing discs containing various antibiotics; and R. Rohringer for critically reading the manuscript.

\section{LITERATURE CITED}

1. Batur, H. 1994. Ein neues Semiselektivmedium für Xanthomonas campestris pv. pelargonii, den Erreger der Stengelfäule und der Blattfleckenkrankheit von Pelargonien. M.Sc. thesis. Institut für Pflanzenpathologie und -schutz, University of Göttingen, Göttingen, Germany.

2. Batur, H., Mavridis, A., and Rudolph, K. 1994. Ein neues Semiselektivmedium für Xanthomonas campestris pv. pelargonii, den Erreger der Stengelfäule und der Blattfleckenkrankheit von Pelargonien. Phytomedizin 24(4):14.

3. Bauer, A. W., Kirby, W. M. M., Sherris, J. C., and Turck, M. 1966. Susceptibility testing by a standardized single disc method. Am. J. Clin. Pathol. 45:493-496.

4. Berthet, A., and Bondar, G. 1915. Molestia bacteriana da mandioca. Bol. Agric. Sâo Paulo 16:513-524.

5. Bradbury, J. F. 1986. Guide to Plant Pathogenic Bacteria. CAB International, Farnham House, Farnham Royal, United Kingdom.

6. Burkholder, W. H. 1942. Three bacterial plant pathogens: Phytomonas caryophylli sp. n., Phytomonas alliicola sp. n., and Phytomonas manihotis (Arthaud-Berthet et Bondar) Viegas. Phytopathology 32:141-149.

7. Chang, F. N. 1979. Lincomycin. Pages 127-143 in: Antibiotica V-1. F. E. Hahn, ed. Springer-Verlag, New York.

8. Chun, W. W. C., and Alvarez, A. M. 1983. A starch-methionine medium for isolation of Xanthomonas campestris pv. campestris from plant debris in soil. Plant Dis. 67:632-635.

9. Daniel, J. F., and Boher, B. 1985. Epiphytic phase of Xanthomonas campestris pathovar manihotis on aerial parts of cassava. Agronomie 5:111-116.

10. Elango, F., and Lozano, J. C. 1980. Transmission of Xanthomonas manihotis in seed of cassava (Manihot esculenta). Plant Dis. 64:784-786.

11. Fessehaie, A. 1997. Biochemical/physiological characterization and detection methods of Xanthomonas campestris pv. manihotis (Berthet-Bondar) Dye 1978, the causal organism of cassava bacterial blight. Ph.D. thesis. Institute of Plant Pathology and Plant Protection, Göttingen University, Göttingen, Germany.

12. Gonzales, J. A. 1987. A procedure for the establishment of seed plants of cassava free of bacterial blight Xanthomonas campestris pv. manihotis. Agron. Trop. 37:75-84.

13. Groussen, F. 1986. Variabilité de Xanthomonas campestris pathovar manihotis. Thesis. L'Institut National Agronomique, Paris-Grignon, France.

14. Hahn, S. K., and Williams, R. J. 1973. Investigation on cassava in the Republic of Zaire. Report to the Commissaire d'État á l'Agriculture. Republic of Zaire. International Institute of Tropical Agriculture, Ibadan, Nigeria.

15. Kahan, F. M., Kahan, J. S., Cassidy, P. J., and Kropp, H. 1974. The mechanism of action of fosfomycin (fosfonomycin). Ann. N.Y. Acad. Sci. 235:364-368.

16. Kariyone, K., Harada, H., Kurita, M., and Takano, T. 1970. Cefazolin, a new semisynthetic cephalosporin antibiotic. Synthesis and chemical properties of Cefazolin. J. Antibiot. 23:131-136.

17. Kelman, A. 1954. The relationship of pathogenicity in Pseudomonas solanacearum to colony appearance in a tetrazolium medium. Phytopathology 44:693-695.

18. Kuan, T.-L., Minsavage, G. V., and Gabrielson, R. L. 1985. Detection of Xanthomonas campestris pv. carotae in carrot seed. Plant Dis. 69:758-760.

19. Leksomboon, C., Thaveechai, N., Kositratana, W., and Paradornuwat, A. 1989. Detection of cassava blight bacteria from leaf and soil. (In Thai, with English summary.) Kasetsart J. 23:228-238.

20. Lozano, J. C., and Sequeira, L. 1974. Bacterial blight of cassava in Colombia: Etiology. Phytopathology 64:74-82.

21. Lozano, J. C., and Zeigler, R. 1990. Breeding for resistance. Pages 334- 
338 in: Methods in Phytobacteriology. Z. Klement, K. Rudolph, and D. C. Sands, eds. Akadémiai Kiadó, Budapest.

22. Maraite, H. 1993. Xanthomonas campestris pathovars on cassava: Cause of bacterial blight and bacterial necrosis. Pages 18-25 in: Xanthomonas. J. G. Swings and E. L. Civerolo, eds. Chapman \& Hall, London.

23. McGuire, R. G., Jones, J. B., and Sasser, M. 1986. Tween media for semiselective isolation of Xanthomonas campestris pv. vesicatoria from soil and plant material. Plant Dis. 70:887-891.

24. Persley, G. J. 1979. Studies on the survival and transmission of Xanthomonas manihotis on cassava seeds. Ann. Appl. Biol. 93:159-166.

25. Roy, M. A., and Sasser, M. 1990. Selective media: Principles of design and use. Pages 61-65 in: Methods in Phytobacteriology. Z. Klement, K. Rudolph, and D. C. Sands, eds. Akadémiai Kiadó, Budapest.

26. Sands, D. C. 1990. Starch hydrolysis: Physiological criteria-Determinative tests. Pages 133-143 in: Methods in Phytobacteriology. Z. Klement, K. Rudolph, and D. C. Sands, eds. Akadémiai Kiadó, Budapest.

27. Schaad, N. W. 1989. Detection and identification of bacteria. Pages 9-16 in: Detection of Bacteria in Seed and Other Plating Material. A. W. Saettler, N. W. Schaad, and D. A. Roth, eds. The American Phytopathological Society, St. Paul, MN.

28. Schaad, N. W., and Stall, R. E. 1988. Xanthomonas. Pages 81-94 in: Laboratory Guide for Identification of Plant Pathogenic Bacteria. N. W. Schaad, ed. The American Phytopathological Society, St. Paul, MN.

29. Schaad, N. W., and White, W. C. 1974. A selective medium for soil isolation and enumeration of Xanthomonas campestris. Phytopathology 64: 876-880.

30. Starr, M. P. 1945. The nutrition of phytopathogenic bacteria. I. Minimal nutritive requirements of the genus Xanthomonas. J. Bacteriol. 51:131-143.
31. Stead, D. E. 1990. Preservation of bacteria. Pages 275-278 in: Methods in Phytobacteriology. Z. Klement, K. Rudolph, and D. C. Sands, eds. Akadémiai Kiadó, Budapest.

32. Terry, E. R. 1976. Cassava bacterial blight in Africa. Pages 23-25 in: The International Exchange and Testing of Cassava Germplasm in Africa. E. R. Terry and R. MacIntyre, eds. International Development Research Centre, Ottawa, Canada.

33. Terry, E., and Ezumah, H. C. 1974. Report on root crops disease survey and evaluation of production problems in Cameroon. International Institute of Tropical Agriculture, Ibadan, Nigeria.

34. Vauterin, L., Hoste, B., Kersters, K., and Swings, J. 1995. Reclassification of Xanthomonas. Int. J. Syst. Bacteriol. 45:472-489.

35. Williams, R. J., Agboola, S. D., and Schneider, R. W. 1973. Bacterial wilt of cassava in Nigeria. Plant Dis. Rep. 57:824-827.

36. Wirth, S. J., and Wolf, G. A. 1992. Micro-plate colourimetric assay for endo-acting cellulase, xylanase, chitinase, 1,3- $\beta$-glucanase and amylase extracted from forest soil horizons. Soil Biol. Biochem. 24:511-519.

37. Woodruff, F. M., Kahan, F. M., Wallick, H., Miller, A. K., and Stapley, E. O. 1975. Fosfomycin, a cell-wall-active antibiotic not inactivated by episome-mediated enzymes. Pages 539-559 in: Microbial Drug Resistance. S. Mitsuhashi and J. Hashimoto, eds. University Park Press, Baltimore.

38. Wydra, K., Fessehaie, A., Fanou, A., Sikirou, R., Janse, J., Verdier, V., and Rudolph, K. 1998. Variability of strains of Xanthomonas campestris pv. manihotis, incitant of cassava bacterial blight, from different geographic origins in pathological, physiological, biochemical and serological characteristics. Pages 317-323 in: Plant Pathogenic Bacteria, Proc. Int. Conf., 9th. A. Mahadevan, ed. Centre for Advanced Study in Botany, University of Madras, India. 